\title{
Happiness and leisure in the Public Place \\ A historical study of Egypt from Ancient Egyptian Age through Coptic Age
}

Prof. Dr. Ahmed Salah El-Din Ouf

Nourhan Abbas El-Zafarany

\begin{abstract}
Urban design and planning are about making the urban experience better for all the urban inhabitants. Happiness/well-being in the past decade has come to focus in research as having a main role in people's quality of life in cities. The Egyptian culture has roots going all the way to the ancient Egyptian cultures and running up to the very unique contemporary context of its society. This research aims at exploring the characteristics of happiness, leisure, and public space during the time from the ancient Egyptian to the end of the Coptic era. This research is part of an attempt to designate the lines of continuity and rupture in the characteristics of happiness, leisure, and the public space along the timeline of Egypt. The research uses a chronological analysis of the happiness beliefs, leisure activities, and public space characters of inclusion, across a period of time spanning over the ages of ancient Egyptians, Hellenic, and Copts. Points of continuity and rupture on the three levels of belief, activity, and space are analyzed across the time under study. The research shows the morphology of some characteristics of happiness belief, leisure activities, and public space, and how some of those continued to be effective in the contemporary Egyptian culture.
\end{abstract}

Keywords: Happiness, Leisure, Public space, Egypt, Ancient Egypt, Coptic Egypt, Ptolemaic Egypt

\section{Introduction}

Urban design and planning is about making the urban experience better for all the urban inhabitants. Happiness/well-being in the past decade has come to focus in research as having a main role in people's quality of life in cities. Psychological research has shown happiness to broaden attention, perception and cognition, and build creative thinking, positive behavior, optimal mental health or flourishing, and pro-social attitudes and behavior. The cumulative nature of positive affect is argued to provide a cumulative history of learning and a causal relation with success. Putting in mind the exchangeable nature of the relationship between individuals' well-being and societal well-being and culture, the study of happiness/well-being at the individual and societal level is significant and vital for the prosperity and quality of life of urban life.

Happiness is a broad term and could be studied from many aspects. In this researcher's point of view, the focus of the study is the role of happiness in the belief system, the reflection of those beliefs in the leisure activities, and the manifestation of those activities in the physical public realm. For the urban designer and planner in Egypt to work for a happier urban experience, the character of the Egyptian from the aspect of happiness has to be thoroughly studied. Some of the characteristics of Egyptian happiness from the level of the belief system, through the practice of leisure activities, and to the public realm, extend their origins across the many phases of culture and history that Egypt went through, all the way back to the ancient Egyptian. 
The ancient Egyptian age, the Fatimid and Mamluk ages, and the long nineteenth century, are the major ages where the Egyptian happiness and leisure characters were formulated and still have lines of continuity that could be traced to this day. In this research the ancient Egyptian age, all the way to the end of the Coptic era, is the focus of the study.

The study is a chronological study on three levels; the belief level, the leisure activities level, and the public space level. In the first level the question of what are the beliefs related to joy and happiness for the ancient Egyptians, is to be discussed through the religious, elite and laymen beliefs and practice. In the second level the activities that could be called leisure activities are described for both the elite and the laymen, related to the rest of their daily lives. On the last level the manifestation of those activities in space is discussed. The study end in tracing the changes that occurred on the different levels during the age that witnessed the fall of that civilization.

\section{Ancient Egypt happiness belief:}

Most literature concerning the ancient Egyptian culture focus on the afterlife and the death culture, especially that most of the surviving archeological sites are tombs and death rituals temples, yet, in the ancient Egyptian culture, happiness was an inherent part of religion as well as the everyday practice. The fleeting nature of the physical form and body were not just acknowledged, but celebrated. That fleeting nature in itself was their motive to live happily (Brier, 2008) (Casson, 1975) (Erman, 1895) (Gosse, 1915). Happiness in that rhetoric was not just subject to luck or fortune, but the making of one's free will. The role of the moods of the Gods, their bliss or fury was still an important part of happiness.

Free will was respected and prioritized throughout the ancient Egyptian culture. A balance between education, work, and pleasure was the sought after life. A life happily lived all the way to death, which was considered a passage to the non-physical realm with the hope of resurrection, was the purpose of living. Happiness was not just celebrated or encouraged by the ancient Egyptian culture and religions, it was sought after and considered a Devine purpose. (GOSSE, 1915)

Although the play of the Gods, as they called it, had a great effect on how affairs were arranged. The natural phenomena were considered signs of gods' bliss or fury. But what a person did accordingly was the defining factor of how their life is painted. The calendar was mainly based on agricultural seasons, but also on weather and natural phenomena, arranged in sets of adversity and favorable days, accordingly one avoids days of peril (bad weather or catastrophic phenomena), and seeks to get things done on favorable days. (Brier, 2008)

The recitations or poems, if they may be called so, composed and recited by the priests of different temples, were concerned with reciting the names of the deities, and hardly some of their characteristics. It was up to the priestesses to perform the musical and dance part of festivals, they clattered and rattled with their "sistra" (the plural of "sistrum", a musical instrument of the percussion family, it consists of a handle and a U-shaped metal frame, made 
of brass or bronze, When shaken the small rings or loops of thin metal on its movable crossbars produce a sound that can be from a soft clank to a loud jangling) and castanets before Hathor or any other deity. The people celebrated religious festivals by dancing to express their joy. Almost every temple had its own festival.(Erman, 1907). On the other hand, the songs composed for the feasts and celebrations in the elite houses could be considered bitter sweet tales, but the main theme still underlined the importance of living life pleasurably and in happiness, due to the eminent fleeting nature of that life. (please note that the literature focused on the translation of the ancient Egyptian poems and songs preferred translating the ancient Egyptian to old English, as follows)

"Men's bodies have returned to the earth since the beginning of time And their place is taken by fresh generations.

As long as Ra rises each morning

And Atum sinks to rest in Manou, So long will men beget and women conceive And through their nostrils they will breathe;

But one day each one that is born must go to his appointed place.

Make a happy day, Oh priest ...

Pass thy day in happiness...

Think on the day when thou must fare to the land where all men are as one.

Never a man hath taken his possessions with him to that land,

And none can thence return" (Brier, 2008)

Another, of similar sentiment,

Follow thy heart and thy happiness as long as thou art on earth.

Consume not thy heart until there cometh for thee that day

When man begs for mercy,

Unless the god whose heart beats no longer hears them who call upon him." (Brier, 2008)

" Celebrate the joyful day!

Let sweet odors and oils be placed for thy nostrils, Wreaths of lotus flowers for the limbs And for the bosom of thy sister, dwelling in thy heart Sitting beside thee.

Let song and music be made before thee.

Cast behind thee all cares and mind thee of pleasure.

Till Cometh the day when we draw towards the land

That loveth silence."

(Erman, 1895)

And:

"Put myrrh on thy head, array thyself in fine linen

Anointing thyself with the true wonders of God. 
Adorn thyself with all the beauty thou canst.

With a beaming face celebrate the joyful day and rest not therein.

For no one can take away his goods with him.

Yea, no one returns again, who has gone hence."

(Erman, 1895)

Throughout all those verses, that were sang during banquets and festivities as the guests were to be engrossed in their conversations and socialization, always capitalized the importance of joy, pleasure and happiness in the earthly life. They underlined that life ends eventually, so one must enjoy it while it lasts. (see Figure (2)

The farmers/peasants expressed their joyful thankfulness to the Gods of agriculture at harvest gathering by dancing. In the festivals annotated for the Goddesses of pleasure; Hathor and Bastet, the crowds were required to dance as it was considered necessary as an expression of joy and a ritual to please those Goddesses (Erman, 1895).

Yet within all of this festivity, the songs always reminded the guests of the fleeting nature of life, the importance of enjoying life and being happy, and at the same time being "good" and remembering that one does not take wealth to the afterlife, but joy and good deeds are key (Casson, 1975). Even at festivals about death and at funerary events, dance, music and songs were an integral part of the rituals performed to please the Gods and bid the deceased farewell (Erman, 1895) (Gosse, 1915).

\section{Ancient Egyptian Work-leisure activities}

In the Ancient Egyptian times, the current definitions of economic environment did not exist. Money did not exist either, there was though a sort of an equivalence system, for example what a certain amount of wheat is worth of a certain amount of copper or silver, and that was used as a reference not as a currency. Barter economy was the main system used to exchange goods, which was on the level of common people very limited. Hence, there haven't been found any sufficient evidence of the existence of market places before the Hellenic era in Egypt. (Brier, 2008)

Egyptians in the ancient times didn't have the idea of the seven-day week. They had neither set work days, nor regular days off. Outside the yearly days off of Nase', and religious and official festivals, the common Egyptian in that time didn't have a defined specific leisure time. Yet, that does not mean that the society back then didn't have any leisure activities, on the contrary, they had a rich leisure life, despite the lack of firm separation lines between leisure and work. (Brier, 2008)

The play or if it might be called leisurely activities was present across all classes, yet in different forms. The common factor between the so called rich or educated classes and the working classes was the love for merry music. Musical instruments were created and used, and songs composed in many fields. The farmers, who had the least so called free time or days off, had their own set 
of songs that they composed and sang for play and encouragement during working the fields. The army had drum tunes to elevate spirits and organize troops. (Brier, 2008)

The well-off class on the other hand had a wider variety of leisure activities. They, just as well, enjoyed music, but with more sophisticated instruments like the harp, accompanied by rhythmic female dancers and singers. Along with the music festivities, the rich enjoyed hunting, fishing, sailing and spectator bull fights. (Brier, 2008)

Classes shared the festivities on the days of feasts, like the five days that celebrate the end of the year (Nasee'), that originally are linked to the flood of the Nile, yet later linked to religious rituals. The religious rituals were performed in city wide festivals depicting parading the Gods across the city, the sharing of food, the offerings, and musical performances. (Brier, 2008) (see Figure (1)

Figure (1) A reconstruction of what the procession of the sacred bull festival might have looked like in the Ancient Egyptian Age (The God Hapis was represented by a Bull)

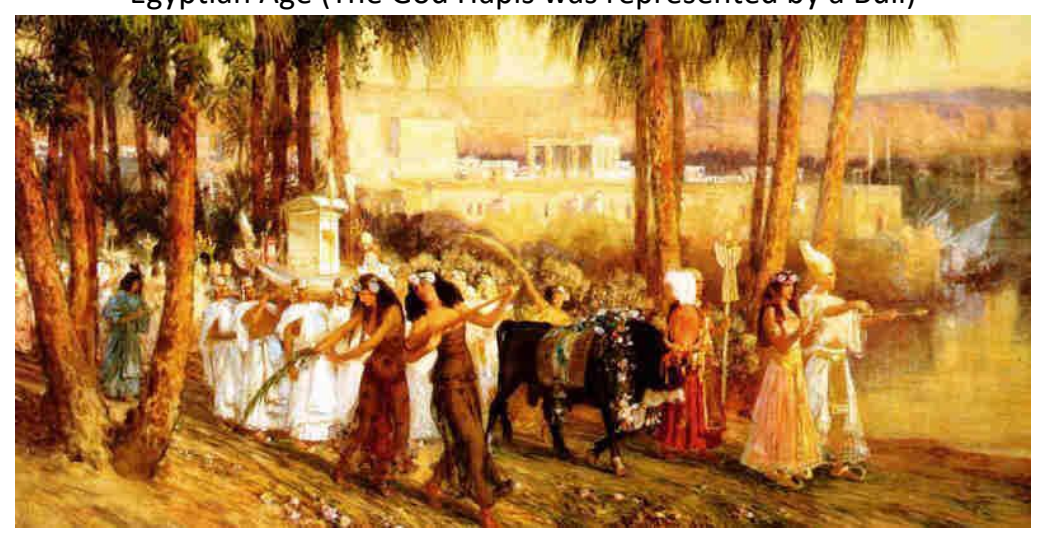

(Experience Ancient Egypt, n.d.)

Figure (2) guests were to be engrossed in their conversations and socialization

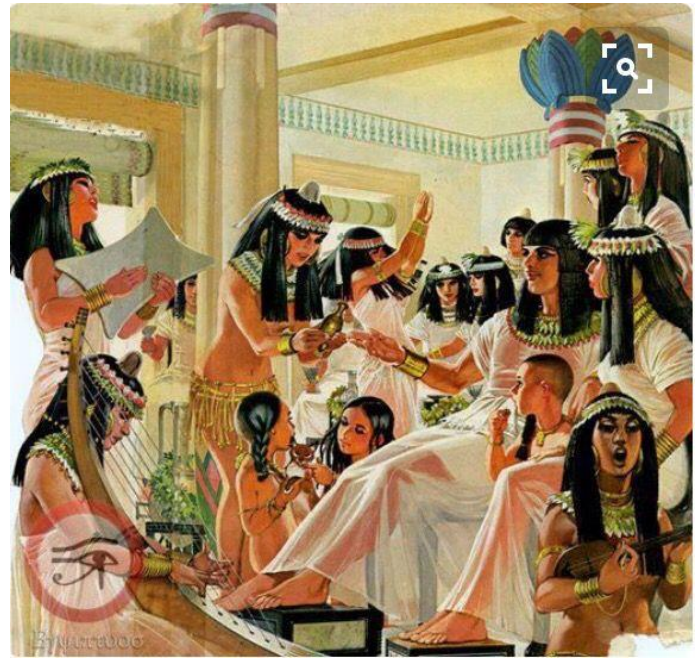

(Pinterest, n.d.) 
The important point to conclude for the activity pattern of the ancient Egyptians, especially the working classes, is the fact that despite the constant working days, the lack of free time, and relatively underprivileged status they were living, they always found a space in their realm for what we call now leisurely activities; activities performed for the purpose of recreation, pleasure, and expressing identity and character. Like the farmers' songs, the raft maker water jousting games, as well as children playing with toys, enjoying tug war and jumping games, and girls playing with stuffed leather balls (Casson, 1975).

\section{Public space}

The line to be drawn between public and private space for the ancient Egyptians was not defined as it is within the western rhetoric. Time was spent mostly working on fields, resting at home, and celebrating feasts. The later might be the main activity that could be called public, and performed in public space, yet it was usually performed in spaces within temples or spaces linked to them. Temple space was the main space containing the public realm, the sharing of festivities, and the non-work friction of classes. (Brier, 2008)

Figure (3) A sketch of the plan of Akhenaten's grand palace complex (after Badawy and Kemp and Garfi) the sketch shows the presence of a significant hall designed for festivals

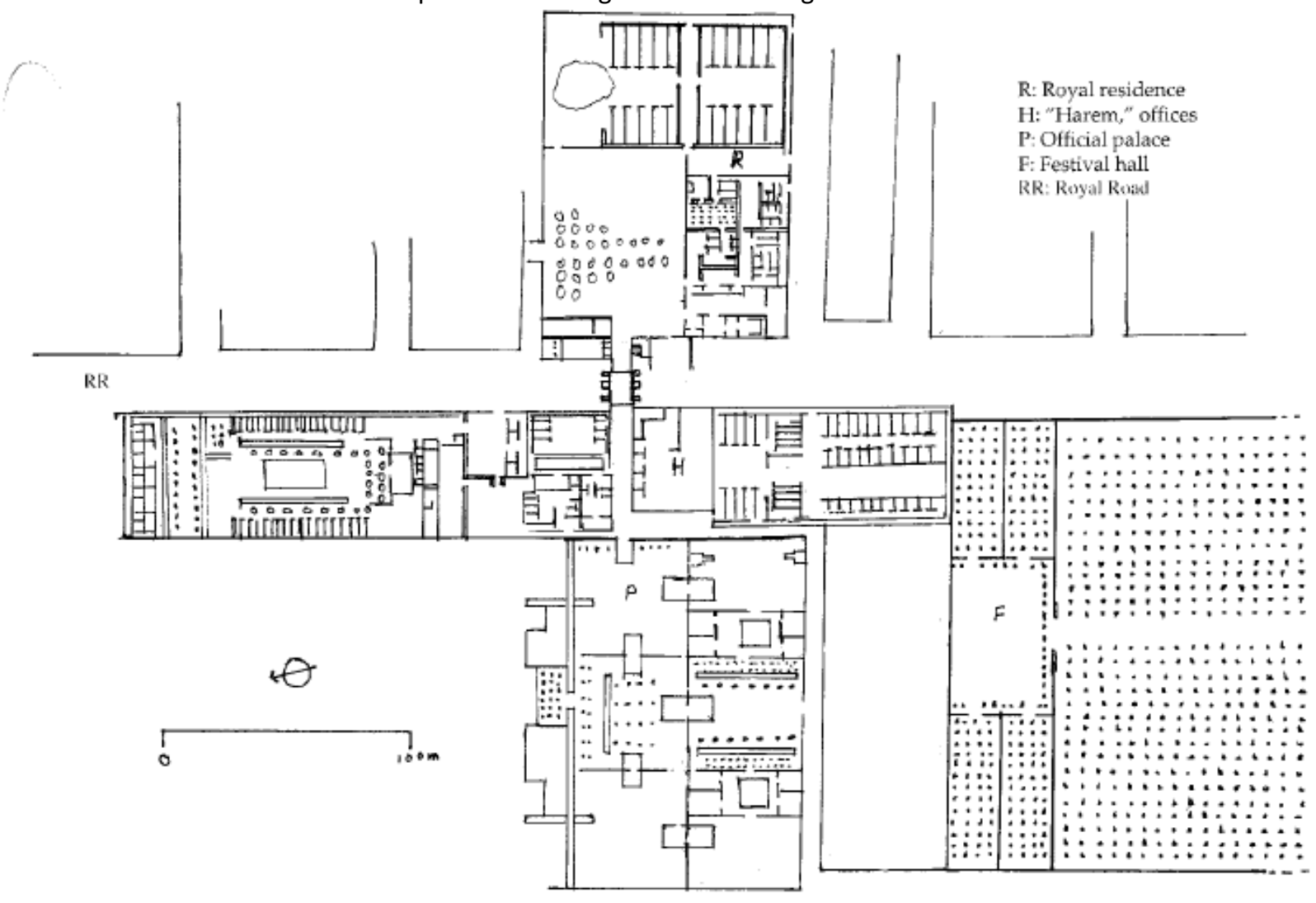

(Brier, 2008)

The leisure activities of the well-off class -royalty, courtiers, the administrators, and elite of ancient Egyptian society- was mainly performed in private or semi-private spaces, like gardens 
and festival/banquet halls (see Figure (3). The consumption of food, beer and wine was a major part of leisure activities in ancient Egypt, the elite could be found in banquet halls around tables piled high with food and beverages, as well as enjoying music, dance and casual conversations (Casson, 1975). Dance was considered a pure expression of joy, in some of their poetic imagery, to rejoice and to dance were used as synonyms. At events female dancers were seen in seethrough attires, performing gymnastic positions, playing with balls, and playing the tambourine for the pleasure of the elite crowd present (see Figure (4). The people, elite or not, saw no offence in watching the revealing clothing and performance of the female dancers (Erman, 1895), much like Egyptians almost to the end of the twentieth century.

Figure (4) Music, singing and dancing would provide the entertainment for the guests as they ate to their heart's content. Flower garlands and perfume cones were provided for them as well. Nebamun (elite, high rank) tomb-

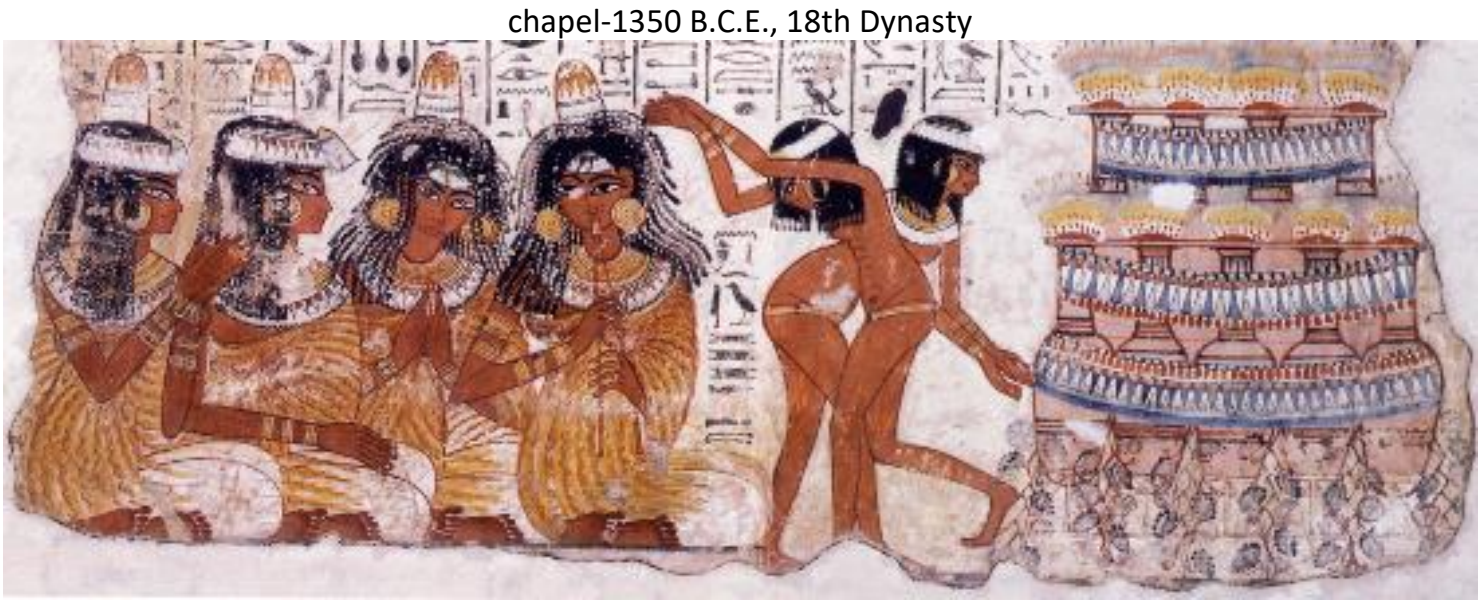

(Experience Ancient Egypt, n.d.)

Figure (5) Nebamun fowling in the marshes, Tomb-chapel of Nebamun, c. 1350 B.C.E., 18th Dynasty, paint on plaster, $83 \times 98 \mathrm{~cm}$, Thebes (C) Trustees of the British Museum

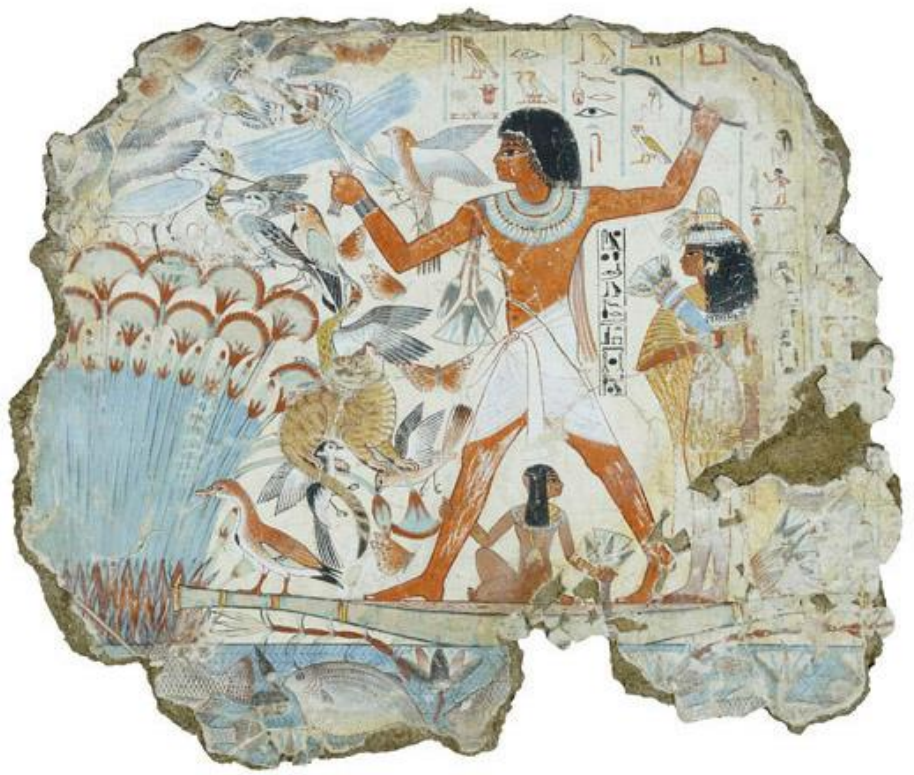

The leisure activity of the rich that was also performed in non-private areas, was sailing the marshes or the backwaters of the Nile, for fishing, nature marveling, and hunting birds and water 
beasts (see Figure (5), acts of pure pleasure, with no utilitarian objective. Hunting wild animals in the desert towards Libya was also a popular sport. Yet all of this was in the open wild, not designed public spaces per say (Erman, 1895) (GOSSE, 1915).

During the ancient Egyptian age, the temples were positioned amidst the towns' buildings, not outside the city. The sacred areas of the temple were protected by the high thick walls from the hustle and bustle of the city, and from direct sunlight. During rituals and celebrations, the path of the God, which is a path leading from the ruling palace to the temple, is where the procession of the celebration takes place, protected on both sides from the crowds by lines of sculptures of sacred animals like rams. The first court of the temple right behind the high gates; pylons, is where most citizens were allowed. The next court is less crowded, and more exclusive to the elite and ruling class. The last of the areas is the holy of the holies, which is where the Gods were said to dwell, where their statue dwelled. The deepest area was protected by high walls, and was the darkest and smallest of the rooms to capitalize on the hierarchy, and was very exclusive. (Erman, 1895)

The hierarchy of spaces of the temple, is a hierarchy in the publicness of space, as well as a hierarchy of inclusion. The space outside the pylon of the temple is the most diverse and inclusive. While the holy of the holies space is the least inclusive, and the most segregating. Between the two extremes of the completely public space outside the pylon, where every citizen is allowed to participate in the event, and the sacred holy space, where only a handful of priests and rulers were allowed, there was a succession of spaces becoming less inclusive as they approach the sacred space. (see Figure (6 and Figure (7)

Figure (6) A 3D reconstruction of Luxor temple ( Eyelid Productions, 2018), illustrated on it the Hierarchy of spaces

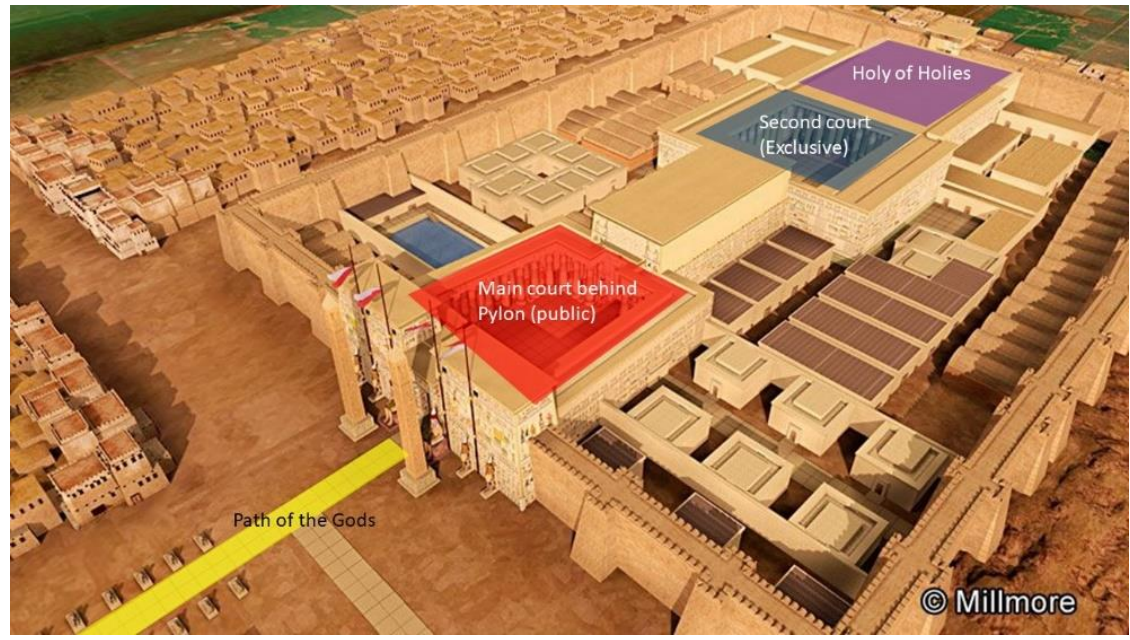

(by researcher) 
Figure (7) Plan of the temple of Rameses III at Medinet Habu, showing a great pylon at the bottom with a series of two open courts behind it, then a great hypostyle hall with two smaller ones behind it, leading to the sanctuary of Amun (with four pillars indicated) at the top.

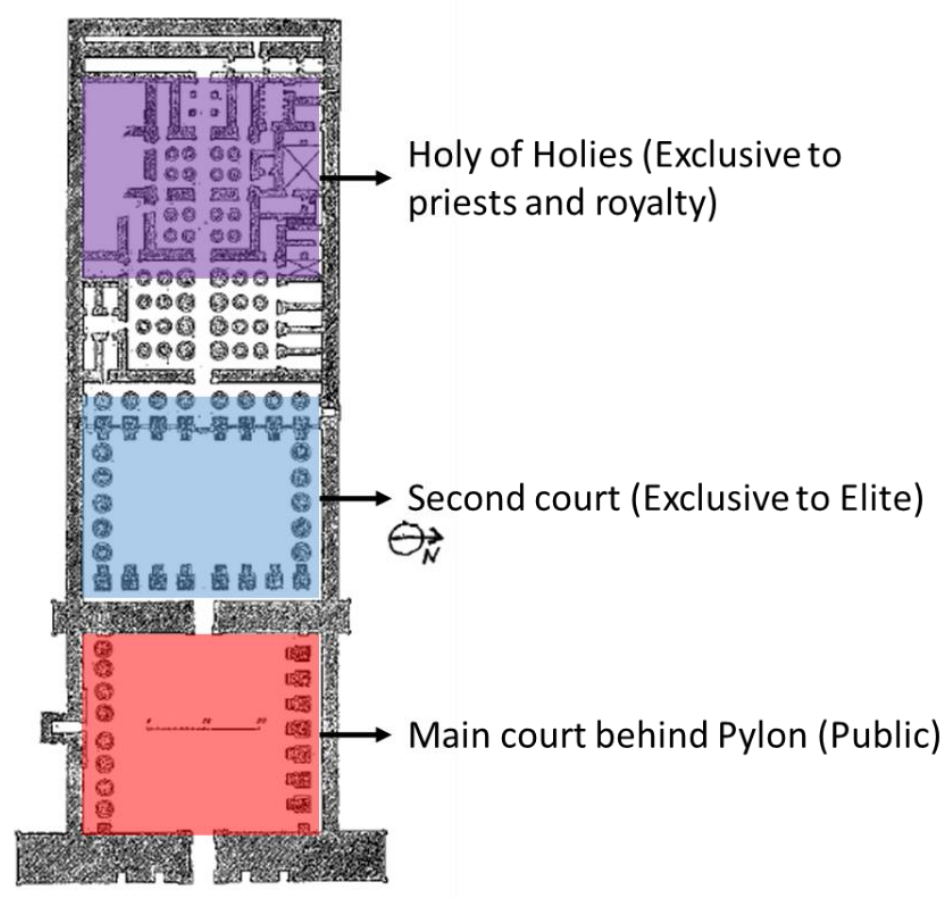

(Brier, 2008)

\section{Hellenistic/Ptolemaic era:}

After Alexander the Great's death, Egypt fell under the hand of Ptolemy. The Hellenistic/Ptolemaic reign on Egypt was characterized mainly by the high friction between the Hellenistic culture and the Egyptian culture. The friction was evident in the separate courts, the translation back and forth from the demotic and the Greek languages, the development of the Egyptian indigenous culture and civilization, as well as the proliferation of the Greek culture especially at the Ptolemaic capital; Alexandria. The Egyptian religion had a clear impact on the Hellenistic religious beliefs, in the form of relating the myths and belief of the main Gods Ammon and Horus to Zeus and Apollo, respectively, as well as the growth of the universal significance of some Egyptian deities like Isis across the Hellenistic states (Encyclopædia Britannica, 2011).

The Ptolemaic era was in part an era of assimilation between the Hellenic culture and the ancient Egyptian culture. Some of the ambitious Egyptians attempted Hellenization as means to move up the social and power hierarchy. The Hellenization was in form of marriage to Greeks, as well as perfecting the Greek language. There was, as well, assimilation in the opposite direction, as the Ptolemaic rulers strengthened the link between the religious beliefs and ruling traditions of the Egyptians and the Hellenic. The Ptolemaic rulers also went along the lines of the ancient Egyptian traditions in building temples and formal urban spaces, like the temple of Kalabsha and Philae. The Ptolemaic era added a layer of rationalism and bureaucracy to the administrative system of Egypt (Sales, 2011). 
Figure (8) Philae Temple in Aswan, a temple originally built in the late ancient Egyptian era (380-362 BC) dedicated for the deity "Isis", most of the surviving structures were built in the Hellenic era (282-145 BC) dedicated to the same deity who was worshiped across the Hellenic kingdom, with many traces of Roman work in Philae dedicated to Ammon-Osiris.

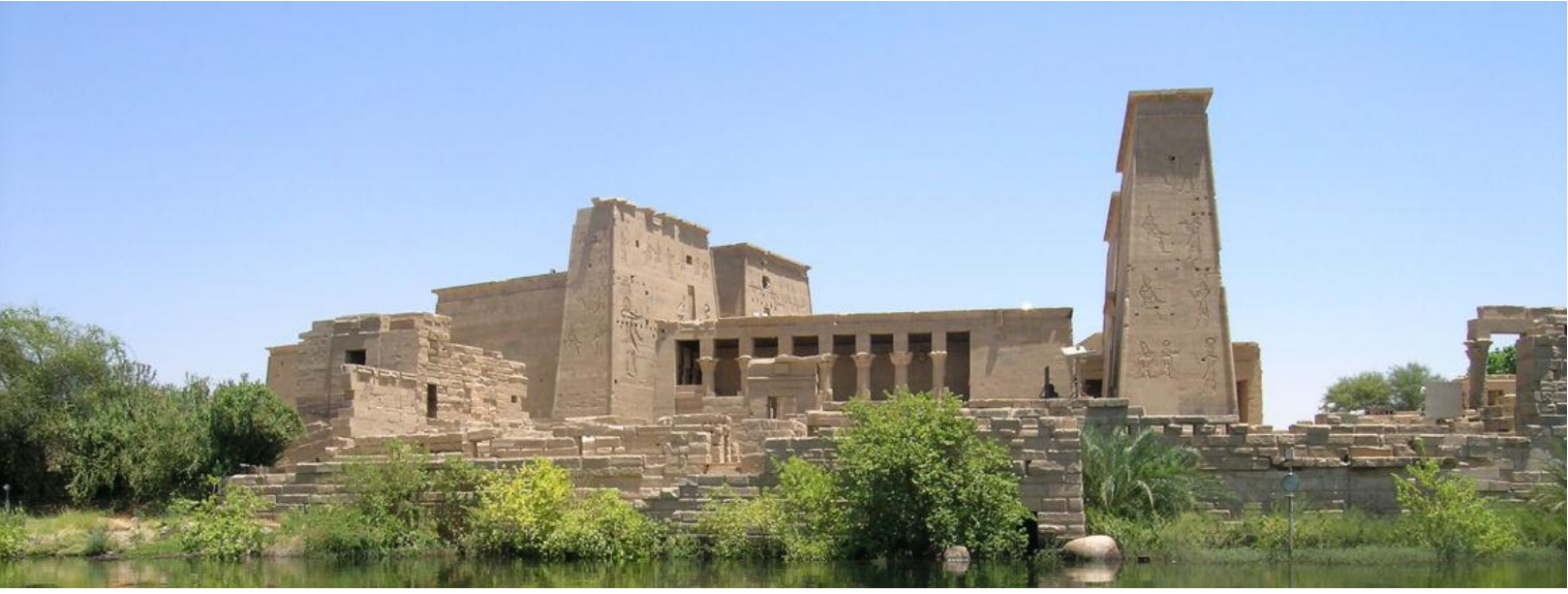

(Marcialis, 2006)

One of the additions of the Hellenic period was the parade art in festivals for non-religious purposes, for purely artistic and leisure purposes. The festivals with multicultural character were prevalent mostly in the city of Alexandria, and quite numerous. The festivals were an expression of the bicultural nature of the Ptolemaic era, and the leisurely nature of life in that era. The festivals depicted Hellenized Egyptian deities, and Egyptianized Greek gods, as well expressing both popular culture and ancestry. The formal celebrations took place in formal spaces like the temple spaces, palace spaces, and agora-like spaces (SOUSA, 2011).

Although the Ptolemaic reign on Egypt left a great mark on the administrative system, the academic development, and the museum scene, it had less effect on the popular culture and the everyday life of cities other than Alexandria. The rulers' adoption of the Egyptian religion and the endorsement of its priests allowed for the beliefs to be sustained, and accordingly the traditions and culture. Also the agglomeration of the Greek communities in the main cities, and in segregated areas from the indigenous people, kept the assimilation at a peripheral zone from the heart of the Egyptian society.

Artistic mastery parading increased in the Ptolemaic era in Egypt, and crossed over from the purely religious form of the ancient Egyptian to the more pleasure aimed of the Ptolemaic. Some activities and establishments were added to the Egyptian public realm. One of those establishments is the public bathhouse, which is a Hellenic addition that didn't exist in the ancient Egyptian era. The bathhouses entailed communal bathing and grooming as a public realm activity. Another addition was the agora and marketplace, or a mixed form of both functions. Trading increased substantially in the Hellenic-Egyptian era posing the need for an organized marketplace. The agora as a political and social public space was introduced to the Egyptian urban 
settlement from the Greek culture, yet in lower status settlements it was used as a social and market space (Davoli, 2011).

\section{Roman and Christian Era:}

The roman era was marked by bloodshed as well as the rise of Christianity. Those two characters left grave marks on the Egyptian character. During the early years of the roman reign on Egypt, although the economy prospered, the country was being ruled in a conqueror ruling the conquered manner, not with the aspiration of assimilation that the Ptolemaic attempted. The class segregation was accentuated and embedded in the legal and judiciary systems, as well as the taxation and tax collection. The priests of temples that enjoyed vast power within the Ptolemaic era got their power minimized and their lands shrunk. Alexandria continued to be a beacon of science and philosophy and structures like what was later called a "Roman theatre" were erected, and still stand to this day at the heart of Alexandria city (Figure (9), yet the state support for the academics shrunk (MILNE, 1913) (Encyclopædia Britannica, 2011). The roman theatre was said to be used both as an academic as well as a leisure space, but the references devoted to the daily activities of the era are limited.

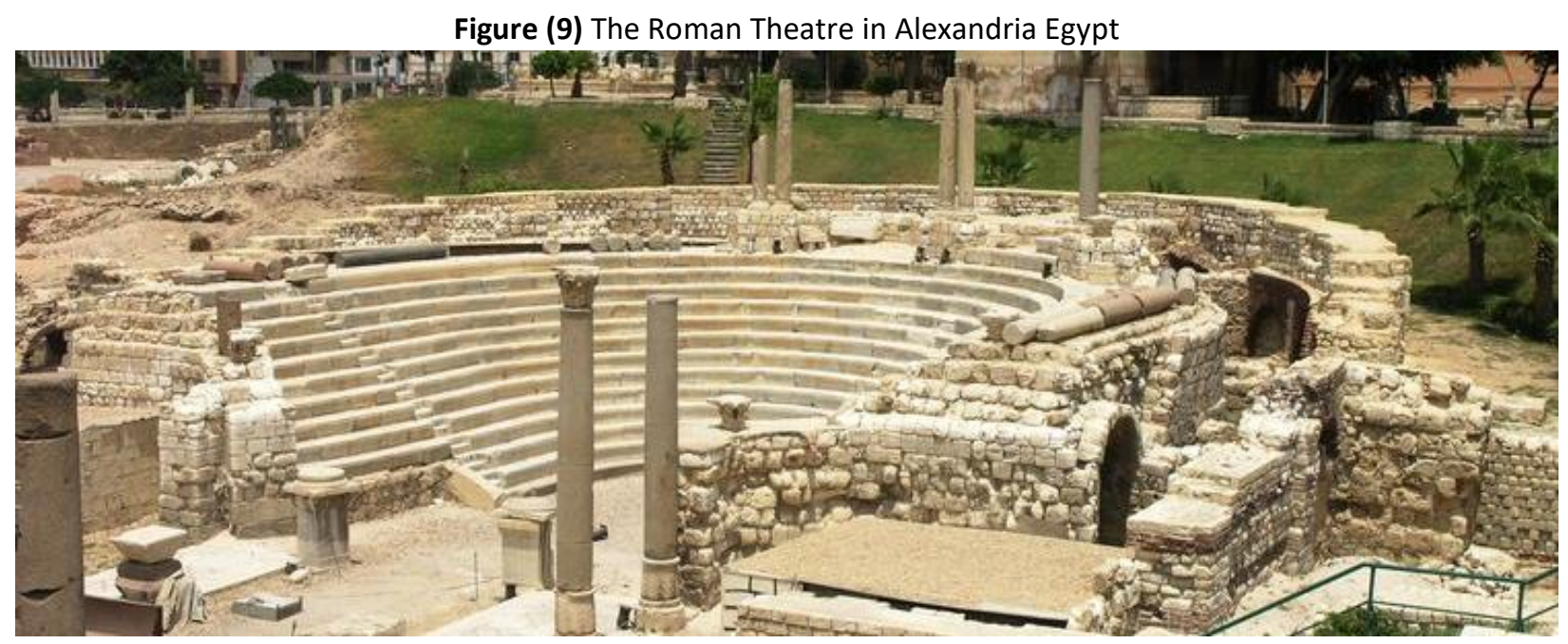

(Mayer, 2016)

The rich got richer, and the poor got poorer. The living situations were declining for the majority of the people. At this point in history the call for the "new way" of "Christ" was initiated. The call was spread in Alexandria first, among the poor and underprivileged. The ideas proposed to the people weren't far off from the ancient Egyptian beliefs, added to it the idea of the savior. Naturally the Christian ideas were accepted and adopted, easily seeping into the Egyptian fabric. The years of early Christianity under the non-Christian roman power were covered in blood due to official prosecution, as well as the instigation of popular massacres. As the power of the Alexandrian church rose, so did its fights, even after the Roman Empire adopted Christianity officially. (Encyclopædia Britannica, 2011) (Davoli, 2011) 
The years of early Christianity maintained some of the characters of the people from the preceding eras, yet it added some of its own characters. One of the newly acquired characters was the change in the view of death. Throughout the ancient Egyptian era, as much as the religions changed, yet the view of death, at the core of the belief, was sustained. It was maintained that death is eminent yet life is to be lived to the fullest and to be grasped as it is fleeting, death was neither to be aspired nor avoided. In the Christian era though, that view changed, martyrdom, death for the survival of the belief was to be worn as a crown, highly valued, and aspired for, by all. Another mark the bloodshed left on the Egyptian people was the aspiration for solitude that spread through the converted Christians in the early years because of oppression and turned into a free choice way of life; monastic life.

On the other hand, some of the aspects of the Egyptians could not be changed, like the affinity for music and song, and the artistic mastery. In the ancient times Egyptians utilized music in religious events, formal events, social events, and all through their daily lives. This was to be sustained in the Coptic culture.

The Coptic culture could be the pinnacle of the marriage between Egyptian, Greek and Christian cultures. The language was Egyptian (demotic) with modified Greek alphabet devised to transliterate the Christian scripture. The art started as a merge of ancient Egyptian and Greek art to express the icons of Christianity, and later the Greek effect was to be set aside and an independent Coptic character was to be developed. The music and song was clearly ancient Egyptian with modified lyrics to fit the new way, but the tunes and instruments were conserved. (Encyclopædia Britannica, 2011)

\section{Analysis:}

\section{Happiness Belief:}

Studying the Happiness beliefs of the ancient Egyptians could be done on three levels of belief; religious, elite daily life, and layman daily life. The religious beliefs, though focused on the afterlife, and the hegemony of the deities over the lives of the people, still had joy at the core of the religion. It was depicted in the description of the life after death by being joyous, and in some instances describing the people as being joyous for the blessings of the gods. The role of pleasure was capitalized as well in the celebration of religious festivals, not just by the people, but by the priests and priestesses as well. Music, poetry, and dancing were a part of the official and popular celebration of religious festivals. (Erman, 1907) this pairing of the spiritual and the pleasurable continued to be the nature of religious events in Egyptian society its modern days.

On the level of the practices of the elite, the songs and tales spun for festivities and feasts, that frequently took place in the royal and elite houses, could be considered a witness on the beliefs of that part of the ancient Egyptian society. The songs that were played during the feasts, that were about socializing, food, wine, and beer, consisted of two main meanings; the eminence of death and consequently the importance of finding the joy and pleasure of life. (Brier, 2008) (Erman, 1895) On the level of the layman the recorded history is very limited, yet the apparent 
from the recordings of the people taking part passionately in religious festivals, as well as incorporating song and dance in their daily work routine, could be considered a mark of holding onto the importance of pleasure and joy amidst the toil of their work life. It is also a sign of linking that pleasure to both their earthly work and efforts, and their spiritual religious belief and practice.

The Ptolemaic reign had little to no effect on the Egyptian beliefs. On the contrary, the Greeks attempted to assimilate with the Egyptian culture and religions. Alexander the great accepted being crowned as a son of the God in Egypt upon his arrival. Many Egyptian deities started having cults in the Hellenic world, like the deity Isis.

Contrary to the Ptolemaic reign that had little to no effect on the characteristics of the Egyptian happiness, the Christianity and the roman blood thirst had a very grave effect. Christianity with its transcendental nature, paired with the bloody nature of the roman era in Egypt, had massive effect of the Egyptian belief system and daily life. The recorded beliefs of the time are mostly the early Christian, which were transcendental, ethical, and had a deep disregard for the earthly life in favor of the afterlife. As opposed to the ancient Egyptian beliefs that paired the eminence of death and the fleeting nature of life to the importance of enjoying that short life, the early Christianity focused on sustaining a pious life of prayer and withstanding suffering for an afterlife of relief.

During the bloodshed that took over the roman era in Egypt, many of the groups facing scrutiny opted for a hermit life of solitude to escape the suffering of life with the fighting humans, to the quite of a life of prayer and spirituality. And amidst the suffering and wars, the religion promised saving from this life of suffering in the afterlife, rather than any promise of happiness in the earthly life.

\section{Leisure activities:}

On the question of activities, a few points have to be set before delving into discussing the leisure activities of the ancient Egyptians. Leisure, in its first definitions, is defined through opposing it with work, it is defined as non-work, or the activities done by choice in the time that is not specified for work activities. For the ancient Egyptians the line between work and leisure was never that clear, especially for the non-elite groups of society, or the laymen. There was no work week, nor days off recorded in historical references of ancient Egyptian daily life. There is no reference to spaces or buildings specified for leisure activities, or even for a market place where leisure activities could take space among commercial activities.

The activities that could be annotated as leisure like singing, dancing, games, and poetry recitation were usually paired with another non-leisure activity or character. Every group of workers in a certain field had their set of songs, that they sang during performing their work toil. (Erman, 1895) That is a character of the Egyptian worker that could be traced to the modern state of Egypt (Lane, 1908). 
Leisure activities of dancing and singing were a prominent feature of religious festivals. In this case activities were still not pure leisure, but a pairing of leisure and religious. Different deities had different festivals accompanied by different songs and performances. Some festivals even required a harp to be played for the deity celebrated to be payed proper respect (Erman, 1907) Well into modern Egypt this pairing of religious festival and leisure activities could be observed in various Mawlids along the year. (Lane, 1908)

The societal group who had time and space allocated for leisure were the royal and elite; the well-off that didn't have to work all the time. The royal palace almost always had a festival hall (Brier, 2008), and some elite houses as well. Purely pleasurable activities were recorded to have taken place during private feasts and celebrations in the houses of the elite, on their tomb walls. Musicians, dancers, singers, wine jars, food feasts, and exchanging pleasantries and gifts between guests were recorded on tomb walls, like the aforementioned Nebamun tomb.

Through the Ptolemaic era leisure activities, though diversified, maintained their core characteristics. On the contrary, the Roman Christian era had a negative effect on the leisure life of the Egyptians. The bloodshed and violent nature of the era minimized what could fall under the name of leisure for the indigenous Egyptians. The apathy towards happiness, and the disregard of the material world and the redirection towards the life after death, decreased the interest in leisure activities and limited them to spiritual rituals. The transcendental nature also had the effect marking many of the leisure activities present before it as pagan and therefore immoral. The stigma had an effect of de-popularizing many of the leisure activities and pushing them underground. Add to that the tight lipped nature of the roman empire at that point in history, which added to the stereotyping and stigmatization of many leisure activities, and especially public performers (Shay, 2014).

In 1895, Adolf Erman, in his book "Life in Ancient Egypt", made a statement that partially stands to this day. The statement was that the passing of time, the rising and ebbing of kingdoms, the multiple conquests, and settlers that passed over the people of Egypt, hardly had any effect on the nature of those people. The change in religion, language, and even a little of mixed race, did not succeed in obliterating the nature of the people of Egypt engraved in their thousands of years old culture. The character and identity coined by the nature of the land that is relatively constant, as well as the long lived civilization of the ancient Egyptian kingdoms (Erman, 1895).

The similarity of character, habits, beliefs, and even some expressions and proverbs, between an ancient Egyptian farmer and a modern day farmer (Fellah), is too striking to ignore. The belief in the good and evil brought by the god in the form of natural phenomena, the great valuing of animals and animal life, the songs composed to encourage farmers to work harder and enjoy their work, and the persistence of finding the time in space in life for recreation through simple things, like food, beverages, songs, and minor sport activities, in both lifetimes are strikingly similar. 
Erman describes the character of the Egyptian people in the nineteenth century as cheerful by nature, yet he claims that they lose their happy temperament and become hardened under the toil of working for others who reap what he sows; literally and figuratively. He also claims that this has been recurrent all through the ages since the ancient Egyptian times till his time in the nineteenth century. Some of the hunted creatures where to be caught alive, for the purpose of keeping as pets, which brings in the leisure activities from the public open wild back to the private realm of the elite (Erman, 1895).

The ancient Egyptian culture and beliefs were engraved into the Egyptian people's mentality across ages. The culture that underwent evolution and development under multiple reigns, keeping at its heart the belief in afterlife, the respect of death and the view of it as a gate to a next life that is based on the one you live. This belief along with the embedded value of happiness and pleasure in the core of the culture and mythology of ancient Egyptians, constructed a life for the people to work hard, be good, yet on top of all, be happy and enjoy life, no matter what social group they belonged to, or what realm they are dwelling within.

\section{Public space:}

When it comes to public spaces, they mostly were formal ritual related spaces, where yearly religious events took place, as well as formal events related to the ruler. Social events were held in semi-public/semi-private spaces of dining or banquet halls in the houses of the elites. The open wild nature was the main space accommodating public leisure activities, as well as farm fields. There is no record of casual or social public spaces in the ancient Egyptian time other than the ritualistic spaces.

The Egyptian culture, stemming from the relatively constant nature of the Egyptian land, survived and grew stronger despite interaction with foreign peoples, conquests, and settlers. Even within the years of the late ancient Egyptian state, the loyalty to the beliefs and traditions of that culture remained strong and found ways to be revived and to survive. Persian invasion and rule might have had an impact on the agriculture and irrigation systems, yet it couldn't penetrate to the core of the culture. At the end of the late period when Alexander the Great banished the Persians and the Libyans, the reasons he was greeted as a friend and a legit ruler of the Egyptian realm were on a lower note- the fact that Greek mercenaries were a huge part of the Egyptian army and its commanders, but -on a much more important note- Alexander's acknowledgment and embracing the Egyptian religion made the greater impact in accepting his rule.

The beliefs of happiness in the ancient Egyptian times, as discussed previously, were integral to the core of the religious belief, and accordingly spread all through the culture. Happiness being at the core of the religious beliefs protected it from being altered by the foreign rule, or the peripheral assimilation of the bicultural nature of the Ptolemaic era. There are no recorded

findings that suggest the beliefs of pleasure and happiness embedded in the Egyptian belief were altered throughout that era. 
A development that had an effect on the public realm was the multi-story apartment building. The apartment buildings usually didn't have the option of a kitchen, therefore cooking was to be done communally or food was to be bought ready-made from street food vendors (Sly, 2013). Ancient Egyptian households had private kitchens (Uphill, 1988), the only record of communal cooking was communal bakeries. Apartment buildings started trending in the Ptolemaic era, with mostly people cooking communally in courtyards between buildings. The trend extended through the Roman Empire, with examples of multi-story buildings with not even courtyard in Rome itself, hence the proliferation of street food vending. There is no specific record of when the street vending took over in Egypt, but records show its trendiness and expansion massively all through the Islamic eras.

\section{Conclusion}

Lines of continuity in the leisure activities are apparent from the ancient Egyptian age to contemporary time. The affinity to socialization and exchanging gifts at celebratory events, as well as the love for music and dance not just during celebrations, but during all activities including non-leisure activities, and the affinity to sharing game time and competing. The love for recreational drinks is apparent along history in Egypt, as well as the current time. Coffee and tea as well as smoking tobacco in its different form were later added to the pallet of recreational consumption, yet the affinity to the character of the activity runs all the way to the ancient Egyptian time. The thin line between work and leisure, despite getting clearer over time, still is thin in some cases, like enjoying songs and music during work toil. During the ancient Egyptian time the concept of a weekly pattern that specifies work days and leisure days did not exist. Though later that form of pattern emerged, the Egyptian workers still prefer to have leisure hours during work days, which can be clearly observed at coffee shops on weekdays.

A thorough survey of the current believes of happiness in Egypt still needs to be conducted, yet through primary observation most characteristics of happiness run all the way back to the ancient Egyptian age as well. The active, social, collectivist, and ecstatic nature of the happiness belief in the Egyptian culture is apparent in the ancient Egyptian culture as much as it is apparent when observing the contemporary representation of culture.

Since leisure is said to be one of the true representations of culture, and especially of happiness beliefs of a culture, observing the activities of Egyptians during feasts, or even during weekends in public places capitalize on the continuity of the lines of happiness characteristics from the ancient Egyptians to the contemporary cultures. In the ancient Egyptian times, there appears to be no public spaces designed specifically for leisure purposes, only a few semi-private spaces within the royal and elite palaces that were designated to festivals could fit that purpose. During festivities in the contemporary days, it could be observed how most of the public realm is appropriated for leisure purposes, even if it is not specifically designed for that. That characteristic shows the continuity of public space practices along the history of Egyptians. Even the affinity to nature is still palpably in the crowds on the waterfronts and parks. The egoist form of happiness is also apparent in the choice of activities. The balance between transcendental and 
earthly beliefs of happiness is apparent in the religious nature of the Egyptians, as well as their love of living life to the fullest, and shunning away from the hermit lifestyle.

The marks left from the Coptic era still have a faint imprint in the contemporary culture as well. The flare for tragedy, and the high saint like role given to martyrs are but a few representations of that imprint. The love for the arts apparent to this day, whether that is the fine arts, music, dance, or theatre and cinema, shows that the Coptic apathy to the pleasures of the body did not survive. What survived is the ancient Egyptian balance between mind and body pleasures, and the mind-body pleasures.

\section{References}

Eyelid Productions, (2018). 3D Reconstruction of Luxor Temple. [Online] Available at: https://discoveringegypt.com/rebuilding-ancient-egyptian-temples-in-3d/3d-reconstruction-of-luxortemple/ [Accessed 12 July 2018].

Brier, B., (2008). Daily life of the ancient Egyptians. Westport, United States of America: Greenwood Press.

Casson, L., (1975). Everyday Life in Ancient Egypt. s.I.:Johns Hopkins University Press.

Davoli, P., (2011). Reflections on Urbanism in Graeco-Roman Egypt: A Historical and Regional Perspective. In: E. Subías, et al. eds. The Space of the city in Graeco-Roman Egypt : image and reality. Tarragona: Institut Català d'Arqueologia Clàssica, pp. 69-92.

Encyclopædia Britannica, (2011). Ancient Egypt: From Prehistory to Islamic Conquest. s.l.:Britannica Educational Publishing.

Erman, A., (1895). Life in Ancient Egypt. London: Macmillan \& Co. .

Erman, A., (1907). A Handbook of Egyptian Religion. London: ARCHIBALD CONSTABLE \& CO. LTD..

Experience Ancient Egypt, (n.d). ANCIENT EGYPTIAN ENTERTAINMENT. [Online] Available at: http://www.experience-ancient-egypt.com/ancient-egyptian-culture/ancient-egyptianlife/ancient-egyptian-entertainment [Accessed 12 July 2018].

Experience Ancient Egypt, n.d. Techniques of Ancient Egyptian Magic. [Online] Available at: http://www.experience-ancient-egypt.com/wp-content/uploads/2015/08/festivalprocession.jpg [Accessed 12 July 2018].

Gosse, B., (1915). The Civilization of the Ancient Egyptians. Virginia: T.C. \& E.C. Jack.

GOSSE, B., (1915). THE CIVILIZATION OF THE ANCIENT EGYPTIANS.. London: T. C. \& E. C. JACK, Ltd..

Lane, E., (1908). The Manners and Customs of Modern Egyptians. London: s.n.

Marcialis, I., (2006). [Online] Available at: https://www.flickr.com/photos/97064431@N00/2383139638/[Accessed 28 August 2018].

Mayer, D., (2016). Roman Theatre, Alexandria. [Online] Available at: $h t t p s: / / w w w . a n c i e n t . e u / i m a g e / 5436 /[$ Accessed 28 August 2018]. 
MILNE, J. G., (1913). A HISTORY OF EGYPT: Under Roman Rule. second ed. London: METHUEN \& CO. LTD.. Pinch, G., (2004). Egyptian Myth: A Very Short Introduction. New York: Oxford Press.

Pinterest, (n.d). 2686 best kemet images on Pinterest. [Online] Available at: https://i.pinimg.com/736x/a9/5b/5f/a95b5fd77a9019dca375d97824614b4b--middleeast.jpg [Accessed 12 July 2018].

Sales, J. d. C., (2011). The Ptolemies: An Unloved and Unknown Dynasty. Contributions to a Different Perspective and Approach. In: Alexandrea ad Aegyptum - The Legacy of Multiculturalism in Antiquity. s.l.:Companhia das Artes - Livros e Distribuição, pp. 35-47.

Sly, D. I., (2013). Philo's Alexandria. s.I.:Routledge.

SOUSA, R., (2011). "LOST IN TRANSLATION»: THE HELLENIZATION OF THE EGYPTIAN TRADITI. In: alexandrea ad aegyptvm: the legacy of multiculturalism in antiquity. s.l.:Companhia das Artes - Livros e Distribuição, pp. 230-264.

Uphill, E. P., (1988). Egyptian towns and cities. Buckinghamshire: Shire Publications LTD. 